\title{
Effect of Continuous and Discontinuous Microwave-Assisted Heating on Starch-Derived Dietary Fiber Production
}

\author{
Kamila Kapusniak ${ }^{1}\left(\right.$,, Karolina Lubas $^{2}$, Malwina Wojcik ${ }^{2}$, Justyna Rosicka-Kaczmarek ${ }^{3}$, Volodymyr Pavlyuk ${ }^{4}(\mathbb{D}$, \\ Karolina Kluziak $^{4}$, Idalina Gonçalves ${ }^{5}\left({ }^{(}\right.$, Joana Lopes ${ }^{5,6}$, Manuel A. Coimbra ${ }^{6}$ (i) and Janusz Kapusniak ${ }^{2, *(1)}$ \\ 1 Department of Biochemistry, Biotechnology and Ecotoxicology, Faculty of Science and Technology, \\ Jan Dlugosz University in Czestochowa, Armii Krajowej 13/15, 42-200 Czestochowa, Poland; \\ k.kapusniak@ujd.edu.pl \\ 2 Department of Dietetics and Food Studies, Faculty of Science and Technology, Jan Dlugosz University in \\ Czestochowa, Armii Krajowej 13/15, 42-200 Czestochowa, Poland; kwrobel292@gmail.com (K.L.); \\ malwinawojcik96@gmail.com (M.W.) \\ 3 Institute of Food Technology and Analysis, Faculty of Biotechnology and Food Sciences, Lodz University of \\ Technology, Stefanowskiego 4/10 Street, 90-924 Lodz, Poland; justyna.rosicka-kaczmarek@p.lodz.pl \\ 4 Institute of Chemistry, Faculty of Science and Technology, Jan Dlugosz University in Czestochowa, Armii \\ Krajowej 13/15, 42-200 Czestochowa, Poland; v.pavlyuk@ujd.edu.pl (V.P.); k.kluziak@ujd.edu.pl (K.K.) \\ 5 CICECO-Aveiro Institute of Materials, Department of Materials and Ceramic Engineering, University of \\ Aveiro, 3810-193 Aveiro, Portugal; idalina@ua.pt (I.G.); lopesjoana@ua.pt (J.L.) \\ 6 LAQV-REQUIMTE, Department of Chemistry, University of Aveiro, 3810-193 Aveiro, Portugal; mac@ua.pt \\ * Correspondence: j.kapusniak@ujd.edu.pl
}

\section{check for} updates

Citation: Kapusniak, K.; Lubas, K.; Wojcik, M.; Rosicka-Kaczmarek, J.;

Pavlyuk, V.; Kluziak, K.; Gonçalves, I.; Lopes, J.; Coimbra, M.A.; Kapusniak,

J. Effect of Continuous and

Discontinuous Microwave-Assisted Heating on Starch-Derived Dietary Fiber Production. Molecules 2021, 26, 5619. https://doi.org/10.3390/ molecules 26185619

Academic Editor: Gregory Chatel

Received: 6 August 2021

Accepted: 13 September 2021

Published: 16 September 2021

Publisher's Note: MDPI stays neutral with regard to jurisdictional claims in published maps and institutional affiliations.

Copyright: (c) 2021 by the authors. Licensee MDPI, Basel, Switzerland. This article is an open access article distributed under the terms and conditions of the Creative Commons Attribution (CC BY) license (https:// creativecommons.org/licenses/by/ $4.0 /)$.

\begin{abstract}
Dietary fiber can be obtained by dextrinization, which occurs while heating starch in the presence of acids. During dextrinization, depolymerization, transglycosylation, and repolymerization occur, leading to structural changes responsible for increasing resistance to starch enzymatic digestion. The conventional dextrinization time can be decreased by using microwave-assisted heating. The main objective of this study was to obtain dietary fiber from acidified potato starch using continuous and discontinuous microwave-assisted heating and to investigate the structure and physicochemical properties of the resulting dextrins. Dextrins were characterized by water solubility, dextrose equivalent, and color parameters $\left(L^{*} a^{*} b^{*}\right)$. Total dietary fiber content was measured according to the AOAC 2009.01 method. Structural and morphological changes were determined by means of SEM, XRD, DSC, and GC-MS analyses. Microwave-assisted dextrinization of potato starch led to light yellow to brownish products with increased solubility in water and diminished crystallinity and gelatinization enthalpy. Dextrinization products contained glycosidic linkages and branched residues not present in native starch, indicative of its conversion into dietary fiber. Thus, microwave-assisted heating can induce structural changes in potato starch, originating products with a high level of dietary fiber content.
\end{abstract}

Keywords: dietary fiber; resistant dextrin; potato starch; modified starch; microwave heating; molecular structure

\section{Introduction}

Nowadays, there is growing interest in the correlation of nutrition with human health. Several studies have been conducted to develop functional foods that provide caloric intake and contain bioactive compounds [1]. Considering its beneficial effects on the human body, dietary fiber (DF) is considered to be part of a group of functional foods. Benefits of adequate intake of DF include prevention of diseases of civilization, such as obesity, cancer, cardiovascular diseases, and diabetes mellitus [2-5]. Some DF also promotes the growth of beneficial gut microbiota [6]. Despite the many advantages of DF consumption, its consumption is still below the recommended intake. The main sources of DF are vegetables, fruits, and whole grains. However, these products are still seldom consumed 
by populations of high-income countries. Improper habits resulting from the consumption of a Western-type diet are the cause of the aforementioned diseases of civilization [7]. For this reason, there is a need to develop new sources of DF that can be successfully added to food to obtain new health-promoting products of better quality and, above all, properties acceptable to consumers.

DF preparations were previously obtained by dextrinization, which occurs while heating starch in the presence of acids [8]. During dextrinization, depolymerization, transglycosylation, and repolymerization occur. As a result of these alterations, new linkages are formed. The decrease in $\alpha 1,4-$ and $\alpha 1,6$-glucosidic digestible linkages, and the increase in non-digestible linkages 1,2- and 1,3-glycosidic in either $\alpha$ - or $\beta$-anomers have been observed [9-12]. This process allowed dextrins resistant to human digestive enzymes to be obtained [13]. Resistant dextrins have been classified as dietary fiber because of their beneficial effect on human health [14]. In recent studies, researchers have used conventional heating to produce starch-derived resistant dextrins. However, the processes were relatively time and energy consuming $[13,15,16]$. Using microwave irradiation as an energy source seems to offer great possibilities for overcoming these drawbacks.

Microwave irradiation is referred to as a type of electromagnetic irradiation in the frequency range from 0.3 to $300 \mathrm{GHz}$ and wavelength from $1 \mathrm{~mm}$ to $1 \mathrm{~m}$ [17]. Microwave irradiation causes the movement of polar molecules or ions. The molecular friction induces energy loss from molecules in the form of heat. For this reason, microwave irradiation has been used for heating different materials [18]. Microwave heating has been reported to shorten the time of various reactions by 10 to 1000 times [19]. Moreover, it is known that microwave irradiation has high repeatability and high efficiency of uniform heating in the whole heated material.

Microwave irradiation has already been used in starch modification [20-22], in which it has allowed starch to be modified in a shorter time than conduction heating [23]. Microwave heating has also been proposed and it has been successfully used to obtain enzyme-resistant dextrins [24]. In the majority of conducted research, common domestic microwave ovens as radiation source were used [20,21,23]. The biggest disadvantage of this type of radiation source is the fact that it typically cannot maintain a constant microwave power [25]. Using a single-mode microwave reactor allowed starch to undergo the dextrinization process under controlled heating conditions at microwave power up to $300 \mathrm{~W}$ [26]. At the same time, it was shown that heating with higher microwave power could cause overheating of the reaction mixture [27]. In order to avoid the risk of overheating, the use of intermittent heating has been proposed [28].

To the best of our knowledge, this article presents, for the first time, a comprehensive and comparative study on dietary fiber obtained from potato starch under continuous and discontinuous microwave heating conditions. It was hypothesized that the discontinuous process would be more effective than the continuous one. In order to confirm this hypothesis, the dextrins obtained by both methods were subjected to structural and physicochemical tests and their properties were compared.

\section{Results and Discussion}

\subsection{Solubility of Dextrins}

The solubility of dextrins at $20^{\circ} \mathrm{C}$ was affected by the microwave-assisted heating conditions, including the microwave power intensity and the processing time (Figure 1). When continuous heating was carried out, the lowest solubility (31.8\%) was observed for the $40 \mathrm{~W} 75 \mathrm{~s}$ sample, while the $50 \mathrm{~W} 90 \mathrm{~s}$ dextrin was the one with the highest solubility $(43.4 \%)$. When using discontinuous heating, the lowest solubility $(48.5 \%)$ was determined for the sample obtained at $100 \mathrm{~W}$ for $15 \mathrm{~s}$, and the highest (81.0\%) for dextrin prepared at $120 \mathrm{~W}$ for $30 \mathrm{~s}$. The dextrins obtained by the discontinuous heating showed higher solubility than dextrins prepared by the continuous heating. Given the same processing time, the higher the radiation power was, the higher the solubility of dextrins was. Moreover, the solubility increased with increasing heating time. Modification of starch caused by 
microwave-assisted heating in the presence of acids resulted in an increase in solubility, similar to dextrins obtained by using conventional heating in the presence of acids $[8,16,29]$. This might be due to the hydrolysis reaction during pyroconversion $[8,13,30]$. The high solubility of dextrins obtained from starch using microwave heating can ensure good homogenization of dextrins in the aqueous environment of food products [31].

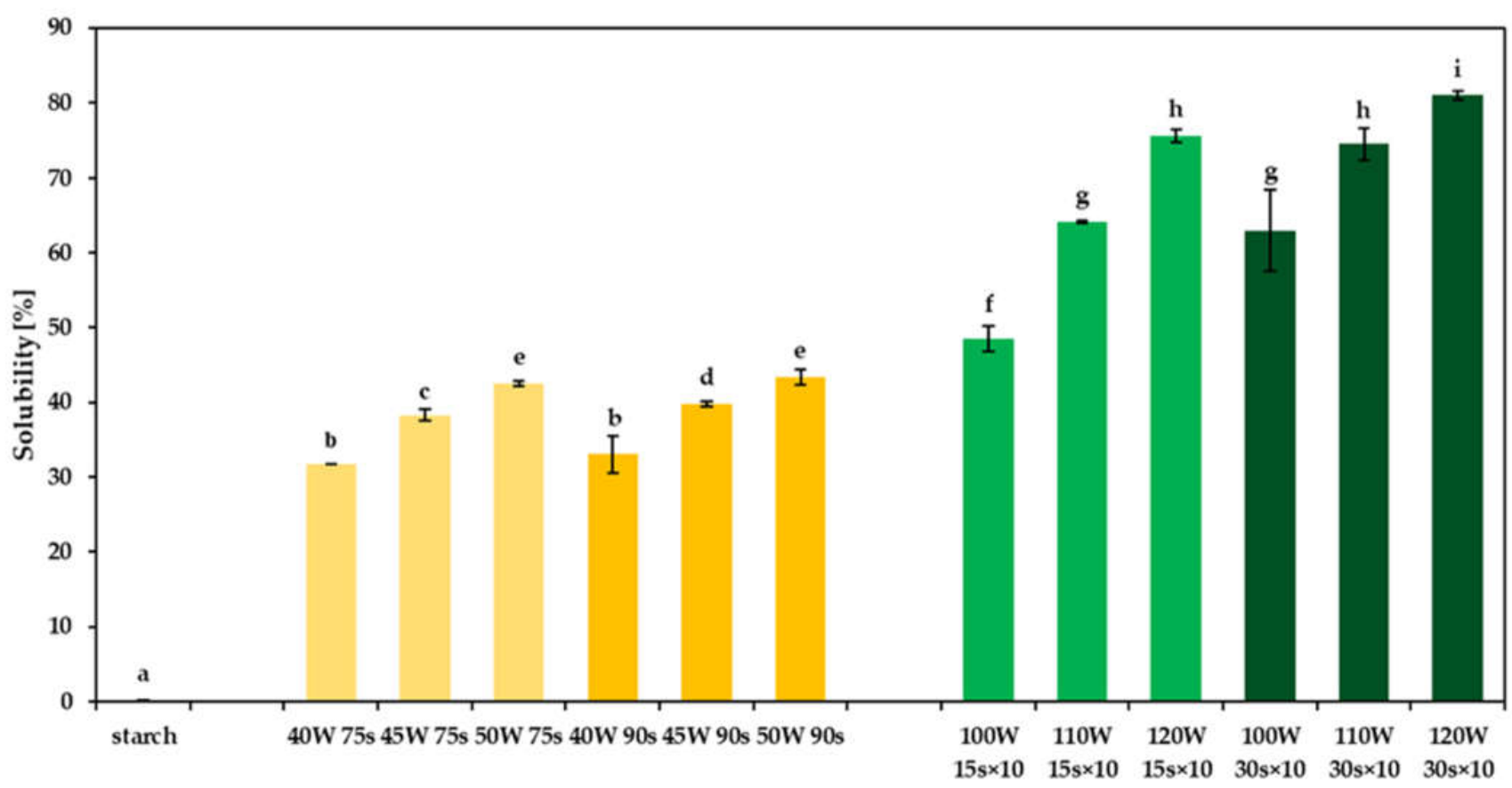

Figure 1. Solubility of dextrins prepared by continuous (yellow) and discontinuous (green) microwave-assisted heating. Different superscript lowercase letters $(a, b, \ldots)$ indicate significant differences $(p<0.05)$ between each dextrin.

\subsection{Dextrins Dextrose Equivalents (DE)}

Although the dextrose equivalents (DE) values (Figure 2) were low for both dextrins obtained by continuous and discontinuous microwave-assisted heating, the ones prepared by the discontinuous heating showed relatively higher $\mathrm{DE}$ values $(\mathrm{DE}=1.52-2.12)$ than the dextrins obtained by continuous heating ( $\mathrm{DE}=0.94-1.47$ ). To have dextrins with such low DE values is important when it is planned to add dextrins into healthy foods without the addition of a high amount of sugars [16]. It can be assumed that, during the heating, a significant depolymerization of starch occurred, as the DE for native potato starch was only 0.2 . It is well known that dextrinization processes significantly increase DE values [12]. A higher modification level of dextrins obtained by discontinuous microwave-assisted heating was confirmed also by their higher solubility values, as shown earlier [24].

\subsection{Color Parameters $\left(L^{*} a^{*} b^{*}\right)$}

After exposure to microwave irradiation, the white color of native potato starch changed (Table 1). All dextrins were characterized by the easily visible color differences, when compared with standard native potato starch, as evidenced by $\Delta \mathrm{E}$ values higher than 5 [13]. Depending on the processing conditions, dextrins with coloration ranging from cream to brown-yellowish were obtained (Figure 3). Positive parameters $a^{*}$ and $b^{*}$ confirm share of red and yellow colors of dextrins The reduction in whiteness and predominance of beige/brown can be related to the progress of the caramelization reaction [12,32,33]. It can be concluded that increasing both the microwave power intensity and the duration of heating allowed to obtain dextrins with an increasingly darker coloration, which is indicated by even lower values of the $L^{*}$ parameter and higher values of the $\Delta \mathrm{E}$ parameter. This is in line with previous observations, which showed that harsher conditions (e.g., 
longer reaction time, higher temperature, or acid concentration) resulted in a darker color of dextrins $[8,12,13,34]$.

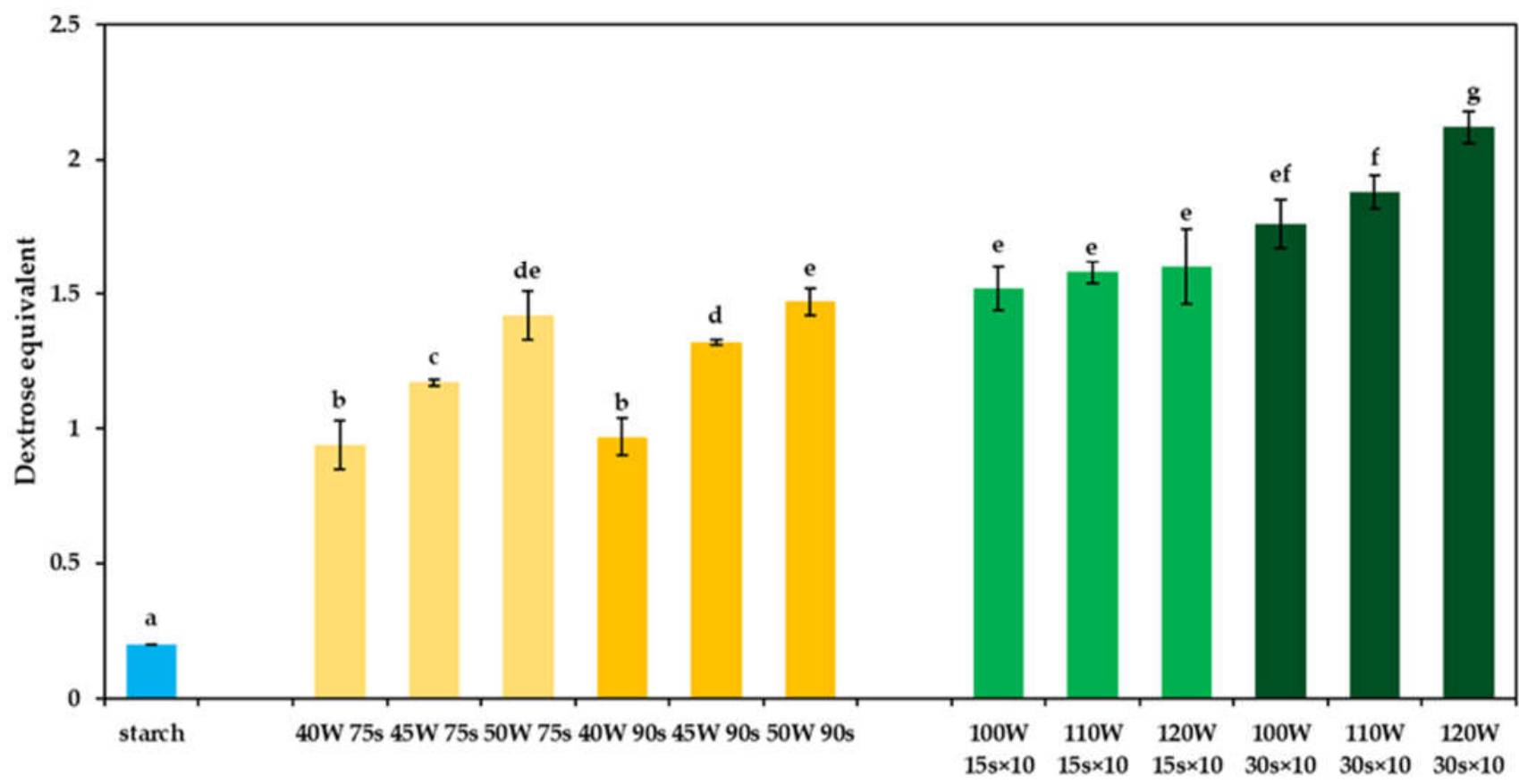

Figure 2. Dextrose equivalent of potato starch (blue) and dextrins prepared by continuous (yellow) and discontinuous (green) microwave-assisted heating. Different superscript lowercase letters $(a, b, \ldots)$ indicate significant differences $(p<0.05)$ between each dextrin.

Table 1. Color parameters of dextrins obtained after exposure of potato starch to continuous and discontinuous microwaveassisted heating, under acidic conditions.

\begin{tabular}{|c|c|c|c|c|}
\hline Dextrin & $L^{*}$ & $a^{*}$ & $b^{*}$ & $\Delta E$ \\
\hline Native potato starch & 94.06 & 0.07 & 1.82 & \\
\hline $40 \mathrm{~W} 75 \mathrm{~s}$ & $88.89 \pm 0.14^{a}$ & $0.56 \pm 0.03^{j}$ & $9.89 \pm 0.11^{h}$ & $9.59 \pm 0.10^{\mathrm{i}}$ \\
\hline $45 \mathrm{~W} 75 \mathrm{~s}$ & $87.31 \pm 0.13^{c}$ & $1.00 \pm 0.04 \mathrm{~g}$ & $10.28 \pm 0.12^{g}$ & $10.86 \pm 0.07^{h}$ \\
\hline $50 \mathrm{~W} 75 \mathrm{~s}$ & $86.69 \pm 0.12^{d}$ & $1.37 \pm 0.04^{\mathrm{f}}$ & $11.14 \pm 0.11^{\mathrm{d}}$ & $11.95 \pm 0.10^{\mathrm{f}}$ \\
\hline $40 \mathrm{~W} 90 \mathrm{~s}$ & $88.00 \pm 0.12^{b}$ & $0.99 \pm 0.04 \mathrm{~g}$ & $10.91 \pm 0.08^{\mathrm{e}}$ & $10.96 \pm 0.08^{h}$ \\
\hline $45 \mathrm{~W} 90 \mathrm{~s}$ & $86.33 \pm 0.09^{d}$ & $1.49 \pm 0.03^{\mathrm{e}}$ & $10.91 \pm 0.07^{\mathrm{e}}$ & $12.02 \pm 0.07^{\mathrm{f}}$ \\
\hline $50 \mathrm{~W} 90 \mathrm{~s}$ & $85.61 \pm 0.14^{\mathrm{e}}$ & $1.52 \pm 0.02^{\mathrm{e}}$ & $10.67 \pm 0.12^{\mathrm{f}}$ & $12.32 \pm 0.06^{\mathrm{e}}$ \\
\hline $100 W 15 s \times 10$ & $88.21 \pm 0.09^{b}$ & $0.67 \pm 0.07^{\mathrm{h}}$ & $8.56 \pm 0.11^{\mathrm{i}}$ & $8.69 \pm 0.08^{j}$ \\
\hline $110 W 15 \mathrm{~s} \times 10$ & $86.95 \pm 0.23^{d}$ & $0.6 \pm 0.05^{\mathrm{i}}$ & $10.94 \pm 0.26^{\text {def }}$ & $11.41 \pm 0.23 \mathrm{~g}$ \\
\hline $120 \mathrm{~W} 15 \mathrm{~s} \times 10$ & $80.44 \pm 0.20 \mathrm{~g}$ & $2.13 \pm 0.05^{\mathrm{d}}$ & $12.87 \pm 0.15^{c}$ & $17.26 \pm 0.12^{\mathrm{d}}$ \\
\hline $100 W 30 s \times 10$ & $81.12 \pm 0.18^{\mathrm{f}}$ & $2.32 \pm 0.08^{c}$ & $14.64 \pm 0.16^{b}$ & $18.03 \pm 0.19^{c}$ \\
\hline $110 W 30 \mathrm{~s} \times 10$ & $79.78 \pm 0.11^{h}$ & $2.71 \pm 0.06^{b}$ & $15.29 \pm 0.22^{a}$ & $19.47 \pm 0.10^{b}$ \\
\hline $120 W 30 \mathrm{~s} \times 10$ & $79.38 \pm 0.25^{\mathrm{i}}$ & $3.07 \pm 0.16^{\mathrm{a}}$ & $15.16 \pm 0.17^{\mathrm{a}}$ & $19.71 \pm 0.12^{\mathrm{a}}$ \\
\hline
\end{tabular}

Different superscript lowercase letters $(a, b, \ldots)$ in the same column indicate significant differences $(p<0.05)$ between each parameter for each dextrin. 


\section{heating time}

$75 s$

90s

$15 s \times 10$

$30 s \times 10$

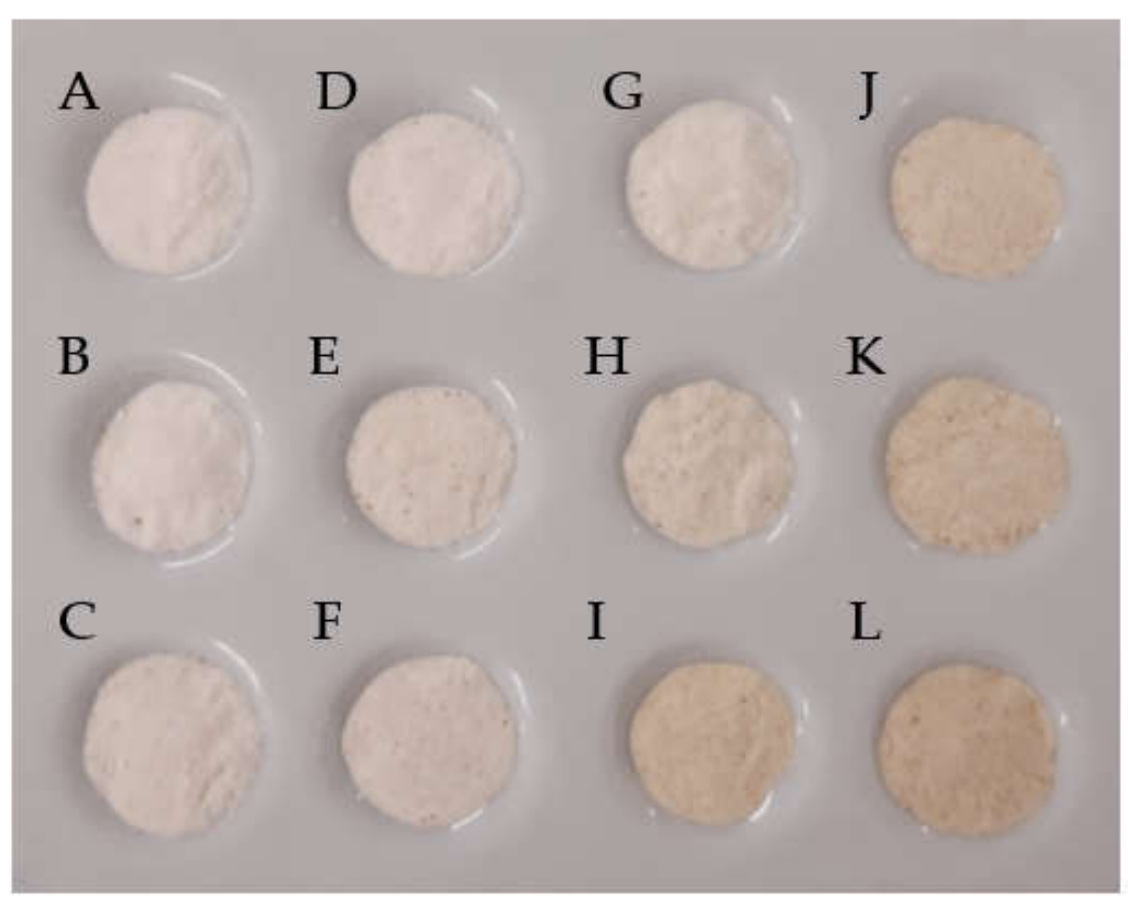

Figure 3. Appearance of dextrins obtained by microwave-assisted heating: continuous-40 W (A,D), $45 \mathrm{~W}(\mathbf{B}, \mathbf{E})$, and $50 \mathrm{~W}(\mathbf{C}, \mathbf{F})$ and discontinuous-100 W $(\mathbf{G}, \mathbf{J}), 110 \mathrm{~W}(\mathbf{H}, \mathbf{K})$, and $120 \mathrm{~W}(\mathbf{I}, \mathbf{L})$.

\subsection{Total Dietary Fiber Content}

Total dietary fiber content for dextrins obtained by continuous microwave-assisted heating ranged from $14.5 \%$ to $21.5 \%$ (Figure 4 ), which was unsatisfactorily low. All dextrins obtained by discontinuous heating were characterized by higher DF content, except dextrin $100 \mathrm{~W} 15 \mathrm{~s}(\mathrm{TDF}=15.6 \%)$ prepared in the mildest conditions among samples heated 10 times. The TDF content increased both with the increasing of microwave power intensity and by extending the heating time. That is in line with other previously published results, where increasing content of non-digestible carbohydrates with increasing process intensity was observed $[13,35,36]$. The highest TDF content amounted to $45 \%$, determined for the dextrins prepared by discontinuous heating of starch at $120 \mathrm{~W}$ for $30 \mathrm{~s}$. This may indicate that the use of microwave-assisted discontinuous heating allows to obtain dextrins with even twice the content of dietary fiber than dextrins obtained by convectional heating of potato starch acidified with the same amounts of hydrochloric and citric acids [11]. Additionally, the proportion in dextrins of high-molecular weight dietary fiber (HMWDF) and low molecular weight dietary fiber soluble in water and not precipitated in $78 \%$ aqueous ethanol (SDFS) varied depending on the conditions of the heating process. In almost all obtained dextrins, the fraction of compounds of low molecular weight constituted the majority. Similar results can be seen in the case of studies conducted by other authors $[35,36]$. 


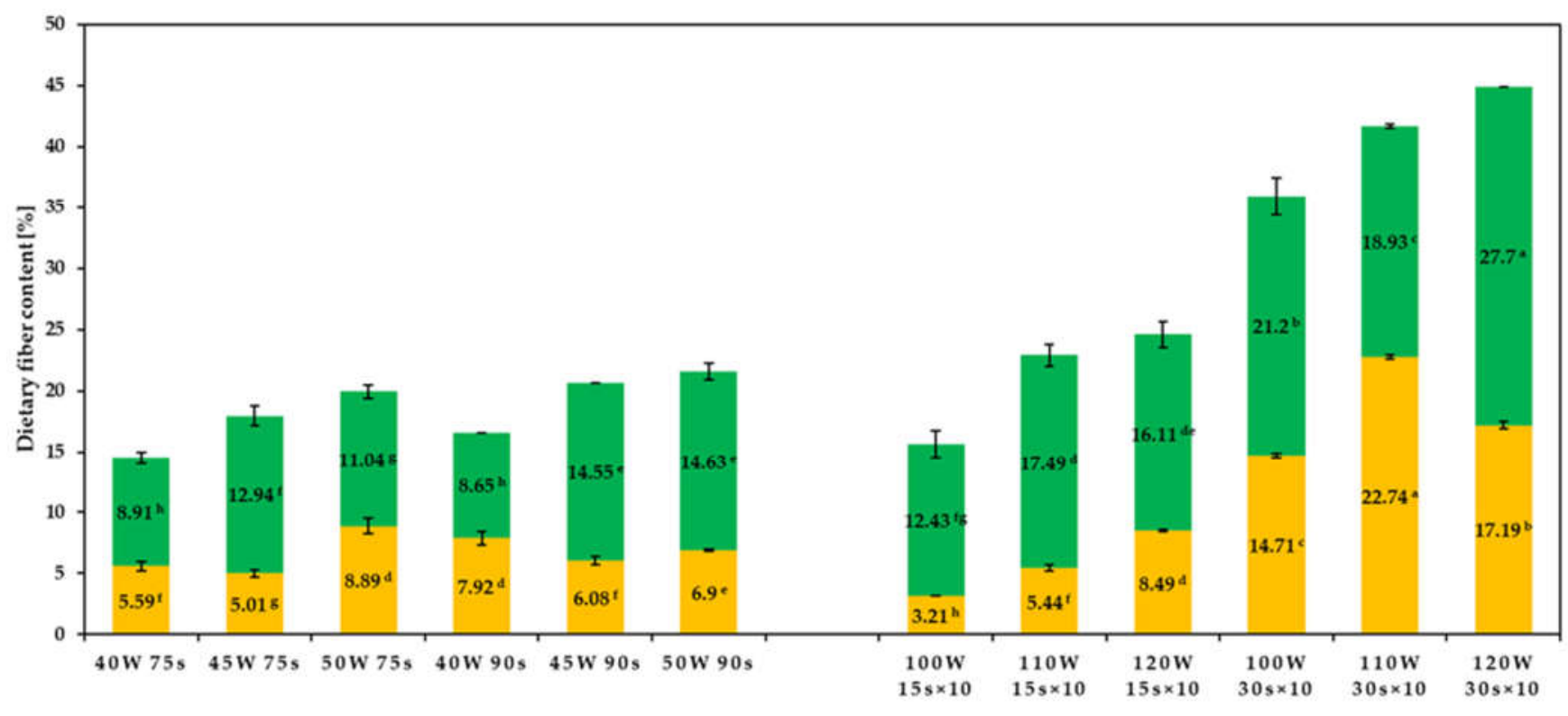

Figure 4. Dietary fiber content of dextrins prepared by continuous (left) and discontinuous (right) microwave-assisted heating. Different superscript lowercase letters $(a, b, \ldots)$ in the same column indicate significant differences $(p<0.05)$ between each parameter for each dextrin.

\subsection{SEM}

Figure 5 shows the influence of microwave-assisted heating on the shape of potato starch granules. In the native form, the potato starch was a mixture of smooth spherical shape granules with a size lower than $20 \mu \mathrm{m}$ and oval shape granules with sizes ranging from $30 \mu \mathrm{m}$ to $60 \mu \mathrm{m}$, possessing edges clearly visible and without damage on their surfaces (Figure 5a). All these characteristics are specific to granules of native potato starch [37]. For starch heated once for $75 \mathrm{~s}$, regardless the microwave power intensity used, the starch granular integrity was maintained. Additionally, single microwave-assisted heating for $90 \mathrm{~s}$ did not cause any significant change in the granular morphology. When exposed to the discontinuous heating, the granular shape of starch was altered (Figure $5 b-g$ ). Noticeable damage on the surface of the granules was observed, while preserving their granular nature, size, and shape. The greatest damage was observed on the surface of larger starch granules. This might be due to the fact that it is easier to gelatinize the larger starch granules than the smaller ones that have higher gelatinization temperatures, thus requiring higher energy and/or processing time till the granules achieve swelling and rupture [38]. Moreover, the magnitude of observed changes increased with the extension of the heating time and the increase in the microwave power intensity. For dextrin obtained by heating 10 times at $120 \mathrm{~W}$ for $30 \mathrm{~s}$, aggregation of starch granules into lumps was observed. This is consistent with the results of other authors concerning changes in starch granules during dry heating treatment [39]. 

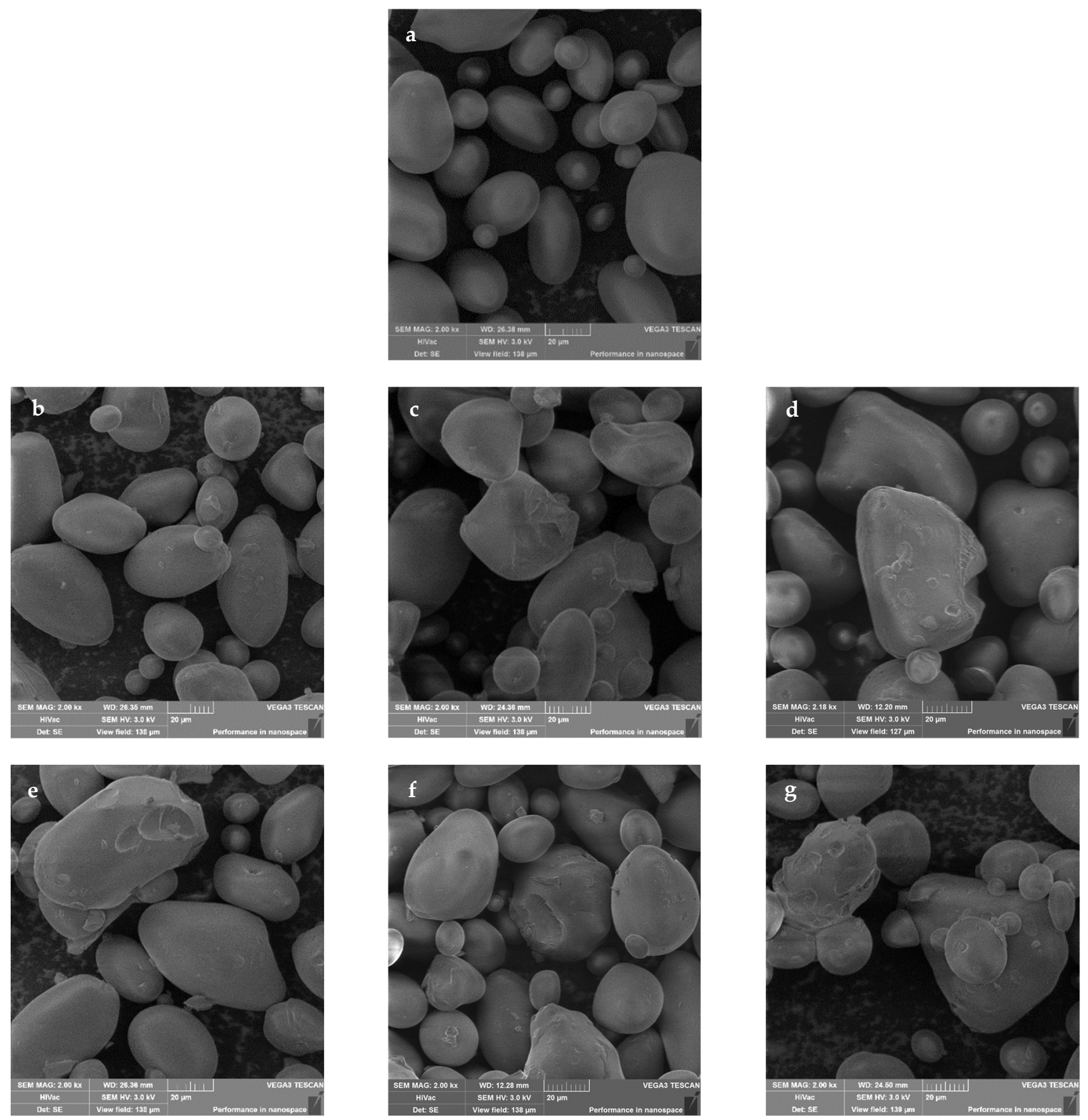

Figure 5. SEM micrographs of native potato starch (a) and obtained dextrins obtained by microwave-assisted heating for $15 \mathrm{~s}$ at $100 \mathrm{~W}(\mathbf{b}), 110 \mathrm{~W}(\mathbf{c})$, and $120 \mathrm{~W}(\mathbf{d})$ and for $30 \mathrm{~s}$ at $100 \mathrm{~W}(\mathbf{e}), 110 \mathrm{~W}(\mathbf{f})$, and $120 \mathrm{~W}(\mathbf{g})$.

\subsection{X-ray Diffraction (XRD)}

The XRD pattern for potato starch contained diffraction peaks $(2 \theta)$ at $5.59^{\circ}, 15.12^{\circ}$, $17.21^{\circ}, 19.54^{\circ}, 22.40^{\circ}, 23.90^{\circ}$, and $26.27^{\circ}$ (Figure 6), which correspond to the B-type crystalline structure of potato starch [40-42]. The potato starch used in this study showed a crystallinity index $\left(\mathrm{X}_{\mathrm{c}}\right)$ of 0.47 . Regardless of the type of microwave-assisted heating used (continuous or discontinuous), a decrease in crystallinity for all the obtained dextrins was observed (Table 2). 

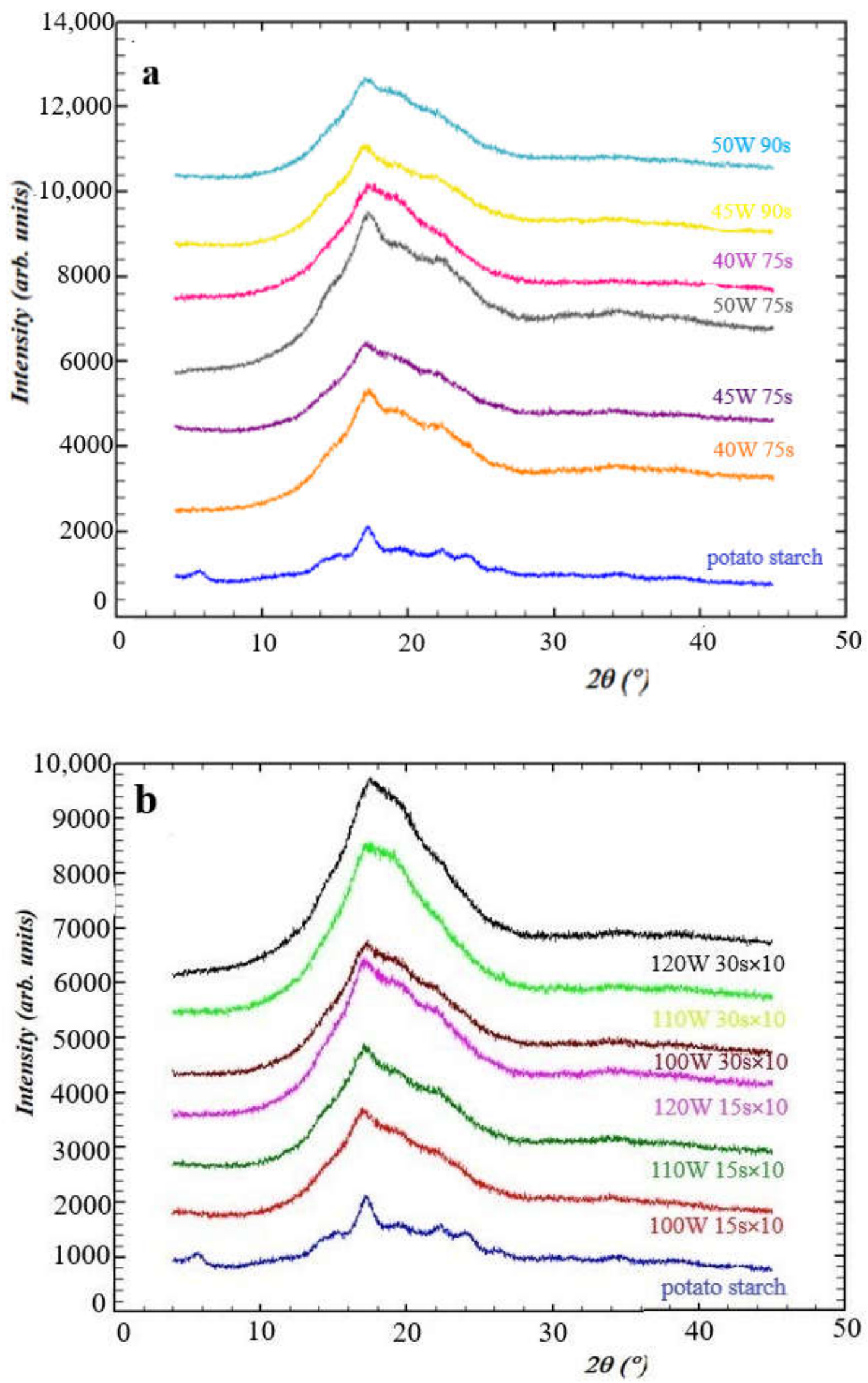

Figure 6. X-ray diffraction patterns of dextrins obtained after heating potato starch under continuous (a) and discontinuous (b) microwave irradiation. 
Table 2. Values of crystallinity index $\left(X_{c}\right)$ dextrins prepared under continuous and discontinuous microwave-assisted heating and native of potato starch.

\begin{tabular}{|c|c|c|}
\hline Sample & $\mathbf{X}_{\mathrm{c}}$ & \\
\hline Native potato starch & 0.47 & \\
\hline $40 \mathrm{~W} 75 \mathrm{~s}$ & 0.28 & \multirow{6}{*}{ 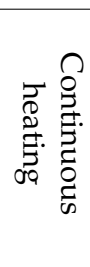 } \\
\hline $45 \mathrm{~W} 75 \mathrm{~s}$ & 0.23 & \\
\hline $50 \mathrm{~W} 75 \mathrm{~s}$ & 0.21 & \\
\hline $40 \mathrm{~W} 90 \mathrm{~s}$ & 0.24 & \\
\hline $45 \mathrm{~W} 90 \mathrm{~s}$ & 0.18 & \\
\hline $50 \mathrm{~W} 90 \mathrm{~s}$ & 0.17 & \\
\hline $100 \mathrm{~W} 15 \mathrm{~s} \times 10$ & 0.24 & \multirow{6}{*}{ 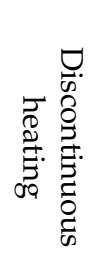 } \\
\hline $110 \mathrm{~W} 15 \mathrm{~s} \times 10$ & 0.22 & \\
\hline $120 \mathrm{~W} 15 \mathrm{~s} \times 10$ & 0.14 & \\
\hline $100 \mathrm{~W} 30 \mathrm{~s} \times 10$ & 0.12 & \\
\hline $110 \mathrm{~W} 30 \mathrm{~s} \times 10$ & 0.10 & \\
\hline $120 \mathrm{~W} 30 \mathrm{~s} \times 10$ & 0.07 & \\
\hline
\end{tabular}

For potato starch continuously heated (Figure 6a), a 2-fold (even 3 times for one sample) decrease in crystallinity was observed, compared with the native potato starch. For potato starch heated once for $75 \mathrm{~s}$ in the microwave reactor, the degree of crystallinity decreased with microwave power increasing. The same behavior was observed for dextrins obtained after heating for $90 \mathrm{~s}$. Comparing the compounds subjected to the same power and different heating times, a slight decrease in the crystallinity of dextrins obtained in the longer heating was observed. For discontinuous heating conditions (Figure 6b), the crystallinity index decreased approximately twice for dextrins obtained at $100 \mathrm{~W}$ and $110 \mathrm{~W}$ for $15 \mathrm{~s}$ and much more for subsequent dextrins-up to almost 7 times for the last one obtained at $120 \mathrm{~W}$ for $30 \mathrm{~s}$. For dextrins heated 10 times for $15 \mathrm{~s}$ or $30 \mathrm{~s}$, it was observed that the higher the power, the lower the crystallinity degree. The crystallinity degree was also influenced by the heating time at a given power. For dextrins heated for $30 \mathrm{~s}$, the crystalline form share was approximately twice as small as in dextrins heated for $15 \mathrm{~s}$. The degree of crystallinity for dextrins heated 10 times for shorter periods of time was lower than for dextrins heated once for longer time. The presented results are in line with the observations of other authors who showed unambiguously that modification of native potato starch by microwave heating at a certain power and time decreased the crystallinity index, which was observed as a decrease or absolute disappearance of diffraction reflections typical for B-type X-ray diffraction pattern $[43,44]$. Consequently, this led to an increase in the amorphous form. The percentage crystallinity decrease verified during dextrinization was also similar to that observed by other authors [30,45-47].

\subsection{Thermal Properties of Dextrins (DSC)}

For dextrins obtained under all tested operational conditions, the temperature values of $\mathrm{T}_{\mathrm{o}}, \mathrm{T}_{\mathrm{p}}$, and $\mathrm{T}_{\mathrm{c}}$ were significantly higher than the ones obtained for the native potato starch (Table 3). These thermal changes indicate that the applied microwave-assisted heating parameters significantly affected the potato starch structure reorganization. $T_{0}, T_{p}$, and $T_{c}$ temperatures characterize the susceptibility of starch to gelatinize and are known to depend on the intra-granular interactions strength [48]. High $T_{o}$ and $T_{p}$ values mean that more energy is required to initiate the starch gelatinization [49]. The obtained results suggest that dextrinization process caused significant changes in the starch crystalline region, resulting in a narrower endothermic gelatinization peak (lower $\Delta \mathrm{T}$ values compared with the native starch) with a lower enthalpy value. Dextrinization, reducing the crystallinity of dextrins (Table 2), simultaneously increased their solubility (Figure 1), dextrose equivalent value (Figure 2), and the share of SDFS soluble dietary fiber (Figure 4). It can be assumed that during the modification of starch, less perfect crystallites with short double helices 
were formed [50]. A good example of clear changes in the crystal structure of starch during its modification are the samples dextrinized under the following conditions: 120 $\mathrm{W} 15 \mathrm{~s} \times 10$ as well as $110 \mathrm{~W}$ and $120 \mathrm{~W} 30 \mathrm{~s} \times 10$, which had the highest dissolving power in water (Figure 1) among all tested dextrins. For these trials, no endothermic transformation during heating was observed in the DSC analysis, indicating the loss of starch crystallinity and gelatinization ability. All depolymerization products obtained showed significantly lower values of $\Delta \mathrm{H}$ than those for native potato starch. The values of $\Delta \mathrm{H}$ are correlated with the degree of starch crystallinity because melting of crystallites (formed by amylopectin) requires more energy [48]. As we have shown, stronger processing conditions, including high microwave power intensity and long operating times, and the method of discontinuous heating, can cause a greater degree of hydrolysis, resulting in a complete loss of the ordered structure of the starch. The greater degree of starch depolymerization resulted, first of all, in a significant increase in the soluble fiber in the tested dextrins and in an increase in their solubility compared with native starch. Based on the thermal analysis data of dextrins, when compared with native potato starch, there was a clear influence of the applied microwave heating power, the processing time, and method of microwave operation (continuous or discontinuous heating) on the degradation of potato starch structure.

Table 3. Gelatinization parameters of dextrins prepared under continuous and discontinuous microwave-assisted heating and native of potato starch.

\begin{tabular}{|c|c|c|c|c|c|}
\hline \multirow{2}{*}{ Dextrin } & To & $\mathrm{Tp}$ & Tc & $\Delta \operatorname{Tr}$ & $\Delta \mathbf{H}$ \\
\hline & \multicolumn{4}{|c|}{$\left({ }^{\circ} \mathrm{C}\right)$} & ( $\mathrm{J} \mathrm{g}^{-1}$ d.w. $)$ \\
\hline Native starch & $58.76 \pm 0.14^{a}$ & $63.23 \pm 0.11^{a}$ & $72.33 \pm 0.15^{a}$ & $13.57 \pm 0.11^{a}$ & $14.30 \pm 0.25^{\mathrm{a}}$ \\
\hline $40 W 75 \mathrm{~s}$ & $60.19 \pm 0.22^{\mathrm{bAA} *}$ & $64.95 \pm 0.16^{\mathrm{bAA} *}$ & $73.01 \pm 0.10^{\mathrm{bAA} *}$ & $12.82 \pm 0.17^{\mathrm{bAA} *}$ & $8.37 \pm 0.17^{\mathrm{bAA} *}$ \\
\hline $45 \mathrm{~W} 75 \mathrm{~s}$ & $62.59 \pm 0.21 \mathrm{cBA} *$ & $66.80 \pm 0.20 \mathrm{cBA} *$ & $74.50 \pm 0.14^{\mathrm{cBA} *}$ & $11.91 \pm 0.10^{\mathrm{cBA} *}$ & $7.90 \pm 0.19 \mathrm{cBA} *$ \\
\hline $50 \mathrm{~W} 75 \mathrm{~s}$ & $63.34 \pm 0.17^{\mathrm{dCA} *}$ & $67.21 \pm 0.19 \mathrm{dCA} *$ & $74.96 \pm 0.21^{\mathrm{dCA} *}$ & $11.62 \pm 0.18^{\mathrm{dCA} *}$ & $4.48 \pm 0.15^{\mathrm{dCA} *}$ \\
\hline $40 \mathrm{~W} 90 \mathrm{~s}$ & $62.35 \pm 0.20^{\mathrm{eAB} *}$ & $70.10 \pm 0.12^{\mathrm{eAB} *}$ & $75.03 \pm 0.11^{\mathrm{eAB} *}$ & $11.22 \pm 0.14^{\mathrm{eAB} *}$ & $3.09 \pm 0.11^{\mathrm{eAB} *}$ \\
\hline $45 \mathrm{~W} 90 \mathrm{~s}$ & $65.87 \pm 0.15^{\mathrm{fBB} *}$ & $71.88 \pm 0.21 \mathrm{fBB} *$ & $75.97 \pm 0.27 \mathrm{fBB} *$ & $10.10 \pm 0.17^{\mathrm{fBB} *}$ & $1.50 \pm 0.21 \mathrm{fBB} *$ \\
\hline $50 \mathrm{~W} 90 \mathrm{~s}$ & $68.96 \pm 0.14 \mathrm{gCB} *$ & $73.90 \pm 0.27 \mathrm{gCB} *$ & $76.91 \pm 0.21 \mathrm{gCB} *$ & $7.95 \pm 0.20 \mathrm{gCB} *$ & $0.50 \pm 0.19 \mathrm{gCB} *$ \\
\hline $100 W 15 s \times 10$ & \multirow{3}{*}{$\begin{array}{c}59.17 \pm 0.21 \text { hAA* } \\
60.75 \pm 0.33^{\text {iBA* }}\end{array}$} & \multirow{3}{*}{$\begin{array}{c}73.85 \pm 0.54 \mathrm{hAA} * \\
66.96 \pm 0.16^{\mathrm{iBA} *}\end{array}$} & $76,74 \pm 0.23^{\mathrm{hAA} *}$ & \multirow{3}{*}{$\begin{array}{c}17.57 \pm 0.21 \text { hAA* } \\
8.80 \pm 0.17^{\text {iBA* }}\end{array}$} & \multirow{3}{*}{$\begin{array}{l}1.30 \pm 0.17^{\mathrm{hAA} *} \\
0.33 \pm 0.15^{\mathrm{iBA} *}\end{array}$} \\
\hline $110 \mathrm{~W} 15 \mathrm{~s} \times 10$ & & & $69.55 \pm 0.21$ iBA* & & \\
\hline $120 W 15 s \times 10$ & & & No endothermic peak & & \\
\hline $100 W 30 \mathrm{~s} \times 10$ & \multirow[t]{3}{*}{$68.23 \pm 0.12^{\mathrm{jAB} *}$} & \multirow[t]{3}{*}{$70.37 \pm 0.24^{\mathrm{jAB} *}$} & $72.97 \pm 0.21^{\mathrm{jAB} *}$ & \multirow[t]{3}{*}{$4.74 \pm 0.24^{\mathrm{jAB} *}$} & \multirow[t]{3}{*}{$0.43 \pm 0.10^{\mathrm{jAB} *}$} \\
\hline $110 W 30 \mathrm{~s} \times 10$ & & & No endothermic peak & & \\
\hline $120 W 30 \mathrm{~s} \times 10$ & & & No endothermic peak & & \\
\hline
\end{tabular}

To, onset temperature; $\mathrm{Tp}$, peak temperature; $\mathrm{Tc}$, conclusion temperature; $\Delta \mathrm{Tr}$, gelatinization temperature range $=(\mathrm{Tc}-\mathrm{To}) ; \Delta \mathrm{H}$, enthalpy expressed in $\mathrm{J} \mathrm{g}^{-1}$ dry starch. Different superscript lowercase letters $(\mathrm{a}, \mathrm{b}, \ldots)$ in the same column indicate significant differences $(p<$ $0.05)$ between each parameter for each dextrin compared with native starch. Different superscript uppercase letters (A, B or C) in the same column indicate significant differences $(p<0.05)$ between each parameter for dextrins from a given series, depending on the microwave power and operating time. Different superscript uppercase letters with asterisk $\left(\mathrm{A}^{*}\right.$ or $\left.\mathrm{B}^{*}\right)$ in the same column indicate significant differences $(p<0.05)$ between each parameter for dextrins with the same microwave power but different operating times.

\subsection{Glycosidic-Linkage Analysis}

According to GC-MS analysis, native potato starch contained more than $90 \%$ of $(1 \rightarrow 4)$-linked Glcp and small amounts of terminal and $(1 \rightarrow 4,6)$-linked Glc $p$ (Table 4$)$. For all dextrin samples, a significant decrease in the percentage of $(1 \rightarrow 4)$-Glc $p$ and a marked increase in terminal and $(1 \rightarrow 6)$-Glc $p$ were observed. The results are in line with observations of Nunes et al. [51], who used dry thermal treatments at $265{ }^{\circ} \mathrm{C}$ for amylose and amylopectin. The majority of the samples contained small amounts of $(1 \rightarrow 2)$ and $(1 \rightarrow 3)$-Glcp. In the context of dextrins' resistance to enzymatic digestion, in addition to the presence of such bonds, the presence of branched molecules, i.e., with more than two groups - $\mathrm{OH}$ involved in the formation of glycosidic bonds, is also beneficial. In each sample low amounts of $(1 \rightarrow 2,4)$ and $(1 \rightarrow 3,4)$-Glc $p$ were presented, and in some dextrin samples it was also possibly to quantify small amounts of $(1 \rightarrow 2,6)$-Glc $p$. Increasing microwave power intensity and heating time seemed to favor the molecules branching. For dextrins 
prepared under continuous and discontinuous microwave-assisted heating, the presence of molecules other than $(1 \rightarrow 4)$-Glc $p$, terminal, and $(1 \rightarrow 4,6)$-Glc $p$ differed depending on the modification conditions used. The values of the relative percentage of non-starch glycosidic linkages ranged from $4.6 \%$ to $7.2 \%$ for samples heated once for $75 \mathrm{~s} ; 8.0 \%$ to $9.2 \%$ for samples heated once for $90 \mathrm{~s} ; 10.6 \%$ to $12.3 \%$ for samples heated 10 times for $15 \mathrm{~s}$; and $13.4 \%$ to $17.3 \%$ for samples heated 10 times for $30 \mathrm{~s}$. These results were in line with the $17.8 \%$ and $5.8 \%$ of linkages other than $(\alpha 1 \rightarrow 4)$ reported by Bai and Shi [52] for pyrodextrin and maltodextrin samples obtained from waxy maize starch.

Table 4. A percentage of different glycosidic linkages of dextrins prepared under continuous and discontinuous microwaveassisted heating and native of potato starch.

\begin{tabular}{|c|c|c|c|c|c|c|c|c|c|c|c|c|c|}
\hline Sample & t-Glcp & $\begin{array}{c}2- \\
\text { Glc } p\end{array}$ & 3-Glcp & 4-Glcp & 6-Glcp & $\begin{array}{c}2,3- \\
\text { Glcp }\end{array}$ & $\begin{array}{c}2,4- \\
\text { Glcp }\end{array}$ & $\begin{array}{c}2,6- \\
\text { Glcp }\end{array}$ & $\begin{array}{c}3,4- \\
\text { Glcp }\end{array}$ & $\begin{array}{c}4,6- \\
\text { Glcp }\end{array}$ & $\begin{array}{l}2,3,6- \\
\text { Glc } p\end{array}$ & $\begin{array}{l}2,4,6- \\
\text { Glcp }\end{array}$ & $\begin{array}{l}3,4,6- \\
\text { Glc } p\end{array}$ \\
\hline potato starch & 3.9 & & & 93.0 & & & & & & 3.1 & & & \\
\hline $40 \mathrm{~W} 75 \mathrm{~s}$ & 9.2 & & & 85.6 & 0.6 & & 0.3 & & 0.3 & 4.1 & & & \\
\hline 45 W $75 \mathrm{~s}$ & 10.0 & & & 84.9 & 0.5 & & 0.3 & & 0.2 & 4.2 & & & \\
\hline $50 \mathrm{~W} 75 \mathrm{~s}$ & 11.0 & 0.4 & 0.4 & 79.0 & 2.3 & & 0.6 & & 0.4 & 5.9 & & & \\
\hline $40 \mathrm{~W} 90 \mathrm{~s}$ & 12.9 & 0.6 & 0.4 & 77.4 & 1.6 & & 0.5 & 0.2 & 0.5 & 5.6 & & 0.1 & 0.2 \\
\hline $45 \mathrm{~W} 90 \mathrm{~s}$ & 10.6 & 0.6 & 0.3 & 79.7 & 1.5 & & 0.6 & 0.1 & 0.5 & 5.9 & & 0.1 & 0.1 \\
\hline $50 \mathrm{~W} 90 \mathrm{~s}$ & 8.2 & 0.6 & 0.2 & 81.5 & 1.2 & & 0.4 & 3.3 & 0.6 & 3.5 & 0.1 & 0.2 & 0.2 \\
\hline $100 \mathrm{~W} 15 \mathrm{~s} \times 10$ & 12.4 & 2.4 & 1.4 & 75.8 & 1.2 & & 0.5 & 0.1 & 0.4 & 5.8 & & & \\
\hline $110 \mathrm{~W} 15 \mathrm{~s} \times 10$ & 15.3 & 0.7 & 0.7 & 68.8 & 4.4 & & 0.8 & & 0.6 & 8.7 & & & \\
\hline $120 \mathrm{~W} 15 \mathrm{~s} \times 10$ & 17.4 & 0.8 & 0.8 & 65.0 & 5.3 & & 0.9 & & 0.6 & 9.1 & & & \\
\hline $100 \mathrm{~W} 30 \mathrm{~s} \times 10$ & 16.2 & 1.0 & 0.8 & 65.0 & 5.3 & & 0.9 & & 0.6 & 9.8 & & 0.2 & 0.2 \\
\hline $110 \mathrm{~W} 30 \mathrm{~s} \times 10$ & 17.9 & 1.2 & 1.1 & 59.6 & 7.1 & & 1.2 & & 0.8 & 11.0 & & & 0.3 \\
\hline $120 \mathrm{~W} 30 \mathrm{~s} \times 10$ & 16.4 & 1.8 & 1.1 & 62.4 & 3.1 & 0.1 & 1.4 & 0.3 & 1.0 & 11.3 & 0.1 & 0.5 & 0.5 \\
\hline
\end{tabular}

\section{Materials and Methods}

\subsection{Materials}

Potato starch and analytical grade reagents were purchased from Sigma-Aldrich, Poznan, Poland; enzymatic kits were purchased from Megazyme, Wicklow, Ireland.

\subsection{Preparation of Dextrins (Continuous and Discountinuous Process) Using Microwave-Assisted Heating}

Dextrins were prepared by weighing $80 \mathrm{~g}$ of potato starch, spreading it onto a glass tray, and spraying it with $0.5 \%(v / v)$ solutions of hydrochloric and citric acids to a final concentration of both acids amounting to $0.1 \% w / w$ related to dry starch basis. Acidified starch was mixed and distributed on the surface of the tray. The prepared material was dried at $110{ }^{\circ} \mathrm{C}$ for $2 \mathrm{~h}$ in order to obtain a final water content of less than $5 \%$. Afterwards, it was weighed $(5 \mathrm{~g})$ into $35 \mathrm{~mL}$ glass vessels and heated in a Discover SP microwave reactor (CEM Corporation, Matthews, NC, USA) at $40 \mathrm{~W}, 45 \mathrm{~W}$ or $50 \mathrm{~W}$ for $75 \mathrm{~s}$ or $90 \mathrm{~s}$, for the continuous process, and at $100 \mathrm{~W}, 110 \mathrm{~W}$ or $120 \mathrm{~W}$ for $15 \mathrm{~s}$ or $30 \mathrm{~s}$, for the discontinuous process. During the continuous process, the samples inside the vessels were heated once, while during the discontinuous process each of the samples inside the vessels was heated 10 times under the selected conditions (the vessels' content was mixed after each heating cycle to increase uniformity of microwave heating and modification of starch level). The different microwave irradiation conditions used in the study and operational advantages and disadvantages are presented in Table 5. Conditions were proposed based on screening tests conducted on a large group of samples. These studies clearly showed that the mildest conditions resulted in white, non-dextrinized samples, while the most extreme conditions favored a caramelization process. Additionally, from our preliminary studies, we found a correlation between lightness and total dietary fiber content (McPearson coefficient was -0.872 ). For this reason, samples could be preliminary selected by color screening. Finally, six dextrins using continuous microwave heating and six by discontinuous heating were prepared and subjected to further analyses. 
Table 5. Microwave irradiation conditions.

\begin{tabular}{cll}
\hline & \multicolumn{1}{c}{ Continuous Heating } & \multicolumn{1}{c}{ Discontinuous Heating } \\
\hline Processing conditions & $\begin{array}{l}40 \mathrm{~W}, 45 \mathrm{~W}, \text { or } 50 \mathrm{~W} \text { for } 75 \text { or } 90 \mathrm{~s} \\
(1 \text { time processed })\end{array}$ & $\begin{array}{l}100 \mathrm{~W}, 110 \mathrm{~W} \text { or } 120 \mathrm{~W} \text { for } 15 \mathrm{~s} \text { or } 30 \mathrm{~s} \\
\text { (10 times processed })\end{array}$ \\
\hline Advantages & $\begin{array}{l}\text { simple, fast, one-step process, better } \\
\text { repeatability }\end{array}$ & $\begin{array}{l}\text { high degree of possible modification, more } \\
\text { homogeneous samples }\end{array}$ \\
\hline Disadvantages & $\begin{array}{l}\text { more heterogeneous samples, low degree of } \\
\text { possible modification }\end{array}$ & longer, 10-step process, worse repeatability \\
\hline
\end{tabular}

\subsection{Solubility of Dextrins}

Solubility in water at $20^{\circ} \mathrm{C}$ was measured according to Richter's method [53]. Dextrins in the amount $0.5 \mathrm{~g}$ were suspended in $40 \mathrm{~mL}$ of distilled water and were stirred at $20^{\circ} \mathrm{C}$ for $30 \mathrm{~min}$. The suspension was subsequently centrifuged at $21,381 \times \mathrm{g}$ for $10 \mathrm{~min}$, and $10 \mathrm{~mL}$ of supernatant was transferred into weighing vessels of known weight. Then, vessels with supernatants were dried to constant weight at $130{ }^{\circ} \mathrm{C}$. Afterwards, the obtained residue was weighed and the solubility (S) in water was calculated using Equation (1):

$$
\mathrm{S}=(100 \times 40 \times \mathrm{b}) /(10 \times \mathrm{a})[\%],
$$

where: $\mathrm{a}$ - sample weight, $\mathrm{b}$ - weight of residue after drying, volume of evaporated supernatant $(10 \mathrm{~mL})$, and total volume of added water $(40 \mathrm{~mL})$.

\subsection{Dextrose Equivalent (DE) of Dextrins}

Dextrose equivalent of dextrins was determined using Schoorl-Regenbogen's method [54]. Dextrins were weighed $(0.5 \mathrm{~g})$, suspended in distilled water $(10 \mathrm{~mL})$, and then stirred at room temperature for $30 \mathrm{~min}$. Then, Fehling's solution I (10 mL), Fehling's solution II $(10 \mathrm{~mL})$, and distilled water $(20 \mathrm{~mL})$ were added, and the mixtures were brought to a boil in $3 \mathrm{~min}$ and boiled for $2 \mathrm{~min}$. After cooling down, potassium iodide $(10 \mathrm{~mL})$, sulfuric acid $(10 \mathrm{~mL})$, and starch colloidal solution $(5 \mathrm{~mL})$ were added, and the mixtures were titrated with sodium thiosulfate. The blank tests were carried out analogically with distilled water. Dextrose equivalent of dextrins was calculated according to [54].

\subsection{Color Parameters $\left(L^{*} a^{*} b^{*}\right)$}

The color of dextrins was measured using a Chroma Meter CR-400 (Konica Minolta Sensing, Osaka, Japan). $L^{*}$ (luminosity), $a^{*}$ (red/green color), $b^{*}$ (yellow/blue color) components were determined with the CIELab color profile. Color difference was calculated from Equation (2):

$$
\Delta E=\sqrt{\left(\Delta L^{*}\right)^{2}+\left(\Delta a^{*}\right)^{2}+\left(\Delta b^{*}\right)^{2}}
$$

where: $\Delta L^{*}, \Delta a^{*}, \Delta b^{*}$ were the differences in the values of $L^{*}, a^{*}, b^{*}$ between native starch and dextrins, respectively. Measurements were performed 10 times for each sample.

\subsection{Total Dietary Fiber Content According to AOAC 2009.01 Method}

High molecular weight dietary fiber (HMWDF), comprising insoluble dietary fiber (IDF) and dietary fiber soluble in water but precipitated in 78\% aqueous ethanol (SDFP), and dietary fiber soluble in water and not precipitated in 78\% aqueous ethanol (SDFS) were determined following the AOAC 2009.01 method [55]. Briefly, the samples were suspended in ethanol and digested with pancreatic $\alpha$-amylase/amyloglucosidase mixture in maleic buffer $(50 \mathrm{mM})$ for $16 \mathrm{~h}$ at $37^{\circ} \mathrm{C}$. The enzymes were inactivated by using TRIS buffer $(0.75 \mathrm{M})$ and boiling. In the next step, the proteins were digested with protease for $30 \mathrm{~min}$ at $60^{\circ} \mathrm{C}$. The enzymes were inactivated by using acetic acid $(2 \mathrm{M})$. Then, ethanol was added to form the HMWDF precipitate. After $1 \mathrm{~h}$, the samples were filtered through vacuum to constant weight and weighed crucibles with diatomaceous earth. The filtrate 
was recovered for SDFS determination. Residues of HMWDF were washed and dried overnight and then used for determination of proteins and ash content. The recovered filtrate was concentrated, deionized, and analyzed with HPLC. Obtained results were used to determine HMWDF and SDFS content in dextrins.

\subsection{SEM}

The granular shape and surface morphology of native potato starch and the prepared dextrins were observed using a Tescan VEGA 3SBU scanning electron microscope (Tescan, Brno, Czech Republic). The accelerating voltage was $3 \mathrm{kV}$. Adhesive tape was attached to circular stubs, then all samples were sprinkled onto tape without coating with any conductive material. All samples were observed, and micrographs were taken at magnification of $\times 2000$.

\subsection{X-ray Diffraction (XRD)}

Phase analysis of dextrins was carried out using powder X-ray diffraction (XRD) Rigaku Miniflex D 600 diffractometer (Rigaku, Tokyo, Japan) with D/teX Ultra silicon strip detector, $\mathrm{Cu}-\mathrm{K} \alpha$ radiation. To assess the crystallinity, the method described by Hulleman et al. [56] was used. The values of the crystallinity index $\left(X_{c}\right)$ for all samples were obtained using Equation (3):

$$
X_{c}=\frac{H_{c}}{\left(H_{c}+H_{a}\right)}
$$

where $H_{c}$ and $H_{a}$ are the intensities for the crystalline and amorphous profiles with typical diffraction reflex (121) at a value of $2 \theta$ between $17^{\circ}$ and $18^{\circ}$, as shown in Figure 7 , respectively. XRD of native potato starch was used as control.

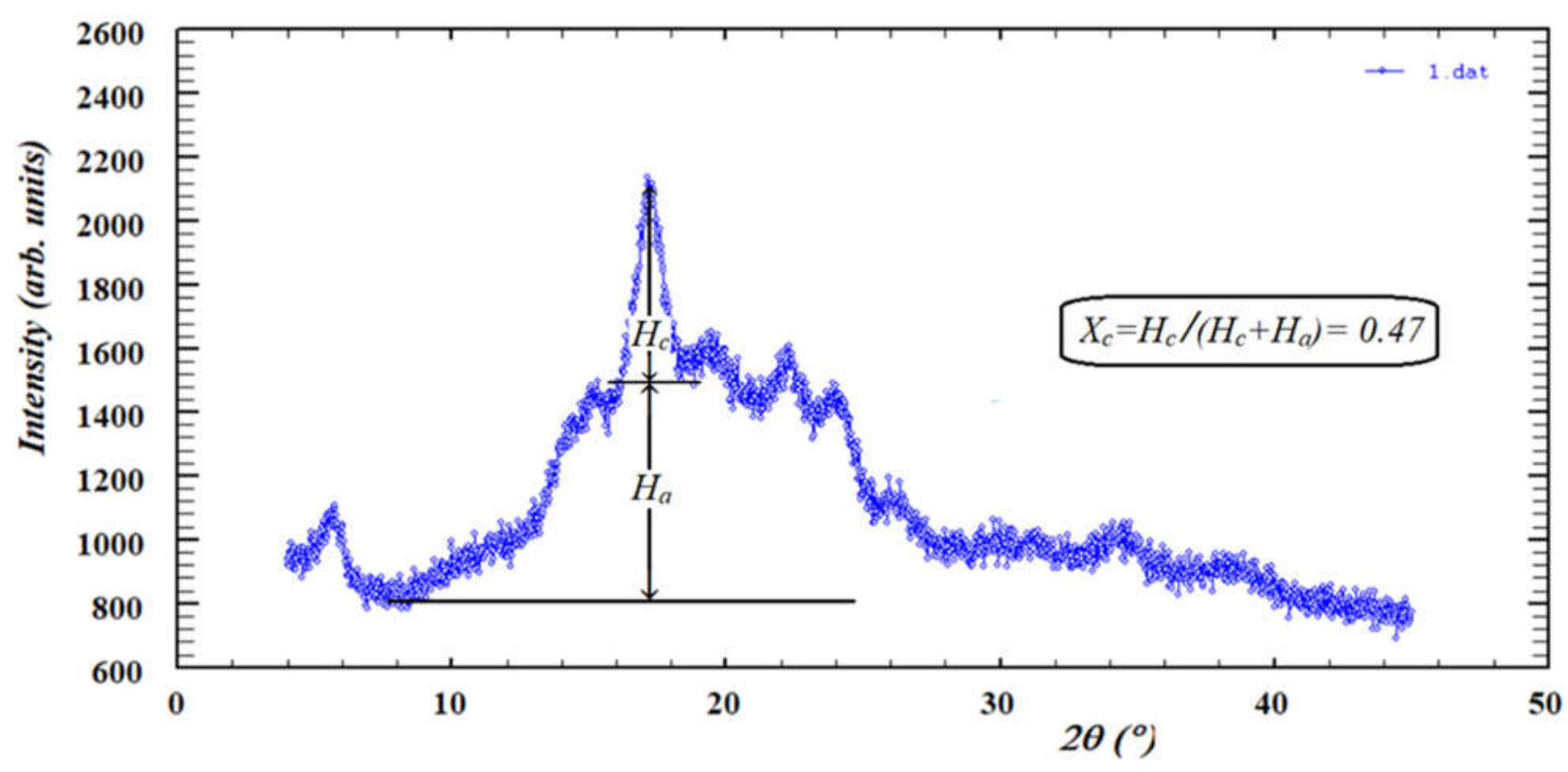

Figure 7. X-ray diffraction patterns for native potato starch. $H_{a}$ and $H_{\mathcal{c}}$ are the amorphous and crystalline profile heights, respectively.

\subsection{Thermal Properties of Dextrins (DSC)}

Gelatinization properties of native starch and dextrins were determined by differential scanning calorimetry (DSC), following a previously described method, but with some modifications [16,57]. For this purpose, a MICRO DSC III differential scanning calorimeter from Setaram Instrumentation (Caluire, France) was used. Triplicate starch samples 
(approximately $40 \mathrm{mg}$ ) were weighed in stainless steel, high-pressure type 'batch' cell at the water/starch ratio of $70: 30(w / w)$. Samples were heated from $10^{\circ} \mathrm{C}$ to $120{ }^{\circ} \mathrm{C}$ at $3{ }^{\circ} \mathrm{C} \min ^{-1}$. The onset $\left(\mathrm{T}_{\mathrm{o}}\right)$, peak $\left(\mathrm{T}_{\mathrm{p}}\right)$, and conclusion $\left(\mathrm{T}_{\mathrm{C}}\right)$ temperatures; gelatinization temperature range $\Delta \mathrm{T}_{\mathrm{r}}=\left(\mathrm{T}_{\mathrm{c}}-\mathrm{T}_{\mathrm{o}}\right)$; and enthalpy change $(\Delta \mathrm{H})$ expressed in $\mathrm{J} \mathrm{g}^{-1}$ dry starch were calculated from thermograms.

\subsection{Methylation Analysis}

For determination of glycosidic linkages composition, dextrins were converted to partially O-methylated alditol acetylates [51]. Briefly, dextrins were dissolved in DMSO overnight, then pellets of $\mathrm{NaOH}$ were added, and the solutions were mixed for $30 \mathrm{~min}$. Then $80 \mu \mathrm{L}$ of $\mathrm{CH}_{3} \mathrm{I}$ was added and allowed to react in room temperature under vigorous stirring. After $20 \mathrm{~min}, 2 \mathrm{~mL}$ of distilled water was added, and the solutions were neutralized with $1 \mathrm{M} \mathrm{HCl}$. Subsequently $3 \mathrm{~mL}$ of dichloromethane was added, and the solutions were manually shaken and further centrifuged at $11,600 \times g$. The water phase was removed, and the precipitate was washed twice with distilled water. The samples were evaporated to dryness. To ensure a complete methylation, this step was repeated. Afterwards, the samples were hydrolyzed with trifluoroacetic acid (TFA) at $121^{\circ} \mathrm{C}$ for $1 \mathrm{~h}$, with subsequent evaporation of the acid. For the carbonyl reduction, $300 \mu \mathrm{L}$ of $2 \mathrm{M} \mathrm{NH}_{3}$ and $20 \mathrm{mg}$ of sodium borodeuteride were added. The mixtures were incubated at $30{ }^{\circ} \mathrm{C}$ for $1 \mathrm{~h}$ and then excess of borodeuteride was removed by addition of glacial acetic acid. The partially methylated alditols were acetylated by adding 1-methylimidazole and acetic anhydride. After $30 \mathrm{~min}$ at $30^{\circ} \mathrm{C}$, the excess of acetic anhydride was removed and the partially Omethylated alditol acetates (PMAA) were extracted with dichloromethane in two steps. Then, the dichloromethane was evaporated, and the samples were dissolved in anhydrous acetone, which was evaporated prior the GC-MS analysis.

\subsection{GC-MS Analysis}

PMAA obtained in the Section 3.9 were analyzed by gas chromatography mass spectrometry (GC-MS) using an Agilent Technologies 6890N Network (Santa Clara, CA, USA). The GC was equipped with a DB-1 column (J\&W Scientific, Folsom, CA, USA). 0.2 $\mu$ L of the samples were injected with the injector operating at $220^{\circ} \mathrm{C}$. The helium carrier gas had a flow rate of $0.2 \mathrm{~mL} / \mathrm{min}$. The GC was connected to an Agilent 5973 (Santa Clara, CA, USA) mass quadrupole selective detector.

\subsection{Statistical Analysis}

The results were subjected to statistical analysis using Statistica 13.3 software (StatSoft, Tulsa, OK, USA). A completely randomized design was applied for all the experiments. Analysis of variance was performed. Mean comparison was done using Duncan's new multiple range test. All assays, except for color measurement (where the tests were repeated 10 times), were performed in triplicate, and their results were averaged if the difference was not statistically significant at $p<0.05$.

\section{Conclusions}

Dextrinization of starch acidified with hydrochloric and citric acids using microwave radiation in a single-mode reactor was successfully carried out. The use of a single-mode microwave reactor allowed high repeatability of conducted processes to be created. The use of discontinuous process (10-fold heating with mixing between cycles) proved to be more effective than the continuous one (single heating). The dextrins obtained by discontinuous heating showed higher solubility and higher content of, among others, $(1 \longrightarrow 2),(1 \longrightarrow 3)$, $(1 \longrightarrow 4,6),(1 \longrightarrow 2,4)$, and $(1 \longrightarrow 3,4)$ Glc $p$ linkages, absent in the native starch, thus highlighting the higher total dietary fiber content. Moreover, the discontinuous heating decreased the starch crystallinity, changing the granules surface morphology and originating samples with higher dextrose equivalent values and darkest coloration, thus revealing 
a more pronounced degree of starch modification. The applied dextrinization processes allowed products with a high total dietary fiber content to be obtained.

Author Contributions: Conceptualization, K.K. (Kamila Kapusniak); methodology, K.K. (Kamila Kapusniak), J.R.-K., V.P., I.G., J.L. and J.K.; validation, K.K. (Kamila Kapusniak); formal analysis, K.K. (Kamila Kapusniak) and J.K.; investigation, K.K. (Kamila Kapusniak), K.L., M.W., J.R.-K., I.G., J.L. and K.K. (Karolina Kluziak); data curation, K.L., M.W. and K.K. (Karolina Kluziak); writing-original draft preparation, K.K. (Kamila Kapusniak), K.L. and M.W.; writing-review and editing, J.R.-K., V.P., I.G., M.A.C. and J.K.; supervision, M.A.C. and J.K.; funding acquisition, K.K. (Kamila Kapusniak). All authors have read and agreed to the published version of the manuscript.

Funding: This research was funded by the National Science Centre, Poland, grant number 2017/25/N /NZ9/02564.

Institutional Review Board Statement: Not applicable.

Informed Consent Statement: Not applicable.

Data Availability Statement: All data are included in the article.

Acknowledgments: The authors would like to thank the financial support from Fundação para a Ciência e Tecnologia and Ministério da Ciência, Tecnologia e Ensino Superior (FCT/MCTES), through the projects LAQV-REQUIMTE (UIDB/50006/2020) and CICECO-Aveiro Institute of Materials (FCT Ref. UIDB/50011/2020 and UIDP/50011/2020). FCT is thanked for the Individual Call to Scientific Employment Stimulus (I.G., CEECIND/00430/2017) and the PhD grant (J.L., SFRH/BD/136804/2018). The Polish National Agency for the Academic Exchange is also thanked for its financial support (PROM Programme-international scholarship exchange).

Conflicts of Interest: The authors declare no conflict of interest.

Sample Availability: Not available.

\section{References}

1. Granato, D.; Nunes, D.S.; Barba, F. An integrated strategy between food chemistry, biology, nutrition, pharmacology, and statistics in the development of functional foods: A proposal. Trends Food Sci. Technol. 2017, 62, 13-22. [CrossRef]

2. Ötles, S.; Ozgoz, S. Health effects of dietary fiber. Acta Sci. Pol. Technol. Aliment. 2014, 13, 191-202. [CrossRef] [PubMed]

3. Yao, B.; Fang, H.; Xu, W.; Yan, Y.; Xu, H.; Liu, Y.; Mo, M.; Zhang, H.; Zhao, Y. Dietary fiber intake and risk of type 2 diabetes: A dose-response analysis of prospective studies. Eur. J. Epidemiol. 2014, 29, 79-88. [CrossRef] [PubMed]

4. Ma, Y.; Hu, M.; Zhou, L.; Lingh, S.; Li, Y.; Kong, B.; Huang, P. Dietary fiber intake and risks of proximal and distal colon cancers: A meta-analysis. Medicine 2018, 97, e11678. [CrossRef]

5. Prasadi, N.V.P.; Joye, I.J. Dietary Fibre from Whole Grains and Their Benefits on Metabolic Health. Nutrients 2020, $12,3045$.

6. Makki, K.; Deehan, E.C.; Walter, J.; Bäckhed, F. The Impact of Dietary Fiber on Gut Microbiota in Host Health and Disease. Cell Host Microbe 2018, 23, 705-715. [CrossRef]

7. O'Keefe, S.J. The association between dietary fibre deficiency and high-income lifestyle-associated diseases: Burkitt's hypothesis revisited. Lancet Gastroenterol. Hepatol. 2019, 4, 984-996. [CrossRef]

8. Chen, J.; Xiao, J.; Wang, Z.; Cheng, H.; Zhang, Y.; Lin, B.; Qin, L.; Bai, Y. Effects of reaction condition on glycosidic linkage structure, physical-chemical properties and in vitro digestibility of pyrodextrins prepared from native waxy maize starch. Food Chem. 2020, 320, 126491. [CrossRef]

9. Ohkuma, K.; Hanno, Y.; Inada, K.; Matsuda, I.; Katta, Y. Process for Preparing Dextrin Containing Food Fiber. U.S. Patent 5620873, 15 April 1997.

10. Wang, Y.J.; Kozłowski, R.; Delgado, G.A. Enzyme resistant dextrins from high amylose corn mutant starches. Starke 2001, 53, 21-26. [CrossRef]

11. Jochym, K.; Kapusniak, J.; Barczynska, R.; Slizewska, K. New starch preparations resistant to enzymatic digestion. J. Sci. Food Agric. 2012, 92, 886-891. [CrossRef]

12. Lovera, M.; de Castro, G.M.C.; da Rocha Pires, N.; do Socorro Rocha Bastos, M.; Holanda-Araujo, M.L.; Laurentin, A.; de Azevedo Moreira, R.; de Oliveira, H.D. Pyrodextrinization of yam (Dioscorea sp.) starch isolated from tubers grown in Brazil and physicochemical characterization of yellow pyrodextrins. Carbohydr. Polym. 2020, 242, 116382. [CrossRef] [PubMed]

13. Trithavisup, K.; Krusong, K.; Tananuwonga, K. In-depth study of the changes in properties and molecular structure of cassava starch during resistant dextrin preparation. Food Chem. 2019, 297, 124996. [CrossRef]

14. Guerin-Deremaux, L.; Li, S.; Pochat, M.; Wils, D.; Mubasher, M.; Reifer, C.; Miller, L.E. Effects of NUTRIOSE ${ }^{\circledR}$ dietary fiber supplementation on body weight, body composition, energy intake, and hunger in overweight men. Int. J. Food Sci. Nutr. 2011, 62, 628-635. [CrossRef] 
15. Huang, Z.; Wang, J.J.; Chen, Y.; Wei, N.; Hou, Y.; Bai, W.; Hu, S.Q. Effect of water-soluble dietary fiber resistant dextrin on flour and bread qualities. Food Chem. 2020, 317, 126452. [CrossRef] [PubMed]

16. Kapusniak, K.; Wojcik, M.; Wrobel, K.; Rosicka-Kaczmarek, J.; Kapusniak, J. Assessment of physicochemical and thermal properties of soluble dextrin fiber from potato starch for use in fruit mousses. J. Sci. Food Agric. 2021, 101, 4125-4133. [CrossRef] [PubMed]

17. Grewal, A.S.; Kumar, K.; Redhu, S.; Bhardwaj, S. Microwave assisted synthesis: A green chemistry approach. Int. J. Appl. Pharm. Sci. Res. 2013, 3, 278-285.

18. Anwar, J.; Shafique, U.; Zaman, W.; Rehman, R.; Salman, M.; Dar, A.; Anzano, J.M.; Ashraf, U.; Ashraf, S. Microwave chemistry: Effect of ions on dieletric heating in microwave ovens. Arab. J. Chem. 2015, 8, 100-104. [CrossRef]

19. Gaba, M.; Passi, N.D. Microwave Chemistry: General Features and Applications. Indian J. Pharm. Educ. Res. 2010, 45, 175-183.

20. Xie, Y.; Yan, M.; Yuan, S.; Sun, S.; Huo, Q. Effect of microwave treatment on the physicochemical properties of potato starch granules. Chem. Cent. J. 2013, 7, 113. [CrossRef] [PubMed]

21. Fan, D.; Wang, L.; Zhang, N.; Xiong, L.; Huang, L.; Zhao, J.; Wang, M.; Zhang, H. Full-time response of starch subjected to microwave heating. Sci. Rep. 2017, 7, 3967. [CrossRef]

22. Shen, H.; Fan, D.; Huang, L.; Gao, Y.; Lian, H.; Zhao, J.; Zhang, H. Effects of microwaves on molecular arrangements in potato starch. RSC Adv. 2017, 7, 14348. [CrossRef]

23. Braşoveanu, M.; Nemţanu, M.R. Behaviour of starch exposed to microwave radiation treatment. Starke 2014, 66, 3-14. [CrossRef]

24. Kapusniak, K.; Nebesny, E. Enzyme-resistant dextrins from potato starch for potential application in the beverage industry. Carbohydr. Polym. 2017, 172, 152-158.

25. Stevenson, D.G.; Biswas, A.; Inglett, G.E. Thermal and Pasting Properties of Microwaved Corn Starch. Starke 2005, 57, 347-353. [CrossRef]

26. Yu, I.K.M.; Fan, J.; Budarin, V.L.; Bouxin, F.P.; Clark, J.H.; Tsang, D.C.W. Evidences of starch-microwave interactions under hydrolytic and pyrolytic conditions. Green Chem. 2020, 22, 7109-7118. [CrossRef]

27. Lukasiewicz, M.; Kowalski, S. Low power microwave-assisted enzymatic esterification of starch. Starke 2012, 64, 188-197. [CrossRef]

28. Horchani, H.; Chaâbouni, M.; Gargouri, Y.; Sayari, A. Solvent-free lipase-catalyzed synthesis of long-chain starch esters using microwave heating: Optimization by response surface methodology. Carbohydr. Polym. 2010, 79, 466-474. [CrossRef]

29. Kaur, M.; Oberoi, D.P.S.; Sogi, D.S.; Gill, B.S. Physicochemical, morphological and pasting properties of acid treated starches from different botanical sources. J. Food Sci. Technol. 2011, 48, 460-465. [CrossRef]

30. Li, H.; Ji, J.; Yang, L.; Lei, N.; Wang, J.; Sun, B. Structrural and physicochemical property changes during pyroconversion of native maize starch. Carbohydr. Polym. 2020, 245, 116560. [CrossRef]

31. Araújo, R.G.; Rodríguez-Jasso, R.M.; Ruiz, H.A.; Govea-Salas, M.; Rosas-Flores, W.; Aguilar-González, M.A.; Pintado, M.E.; Lopez-Badillo, C.; Luevanos, C.; Aguilar, C.N. Hydrothermal-Microwave Processing for Starch Extraction from Mexican Avocado Seeds: Operational Conditions and Characterization. Processes 2020, 8, 759. [CrossRef]

32. Toraya-Aviles, R.; Segura-Campos, M.; Chel-Guerrero, L.; Betancur-Ancona, D. Effects of pyroconversion and enzymatic hydrolysis on indigestible starch content and physicochemical properties of cassava (Manihot esculenta) starch. Starke 2016, 69, 1600267. [CrossRef]

33. Kumar, Y.; Singh, L.; Sharanagat, V.S.; Patel, A.; Kumar, K. Effect of microwave treatment (low power and varying time) on potato starch: Microstructure, thermo-functional, pasting and rheological properties. Int. J. Biol. Macromol. 2020, 155, 27-35. [CrossRef] [PubMed]

34. Lin, C.-L.; Lin, J.-H.; Zeng, H.-M.; Wu, Y.-H.; Chang, Y.-H. Indigestible pyrodextrins prepared from corn starch in the presence of glacial acetic acid. Carbohydr. Polym. 2018, 188, 68-75. [CrossRef] [PubMed]

35. Weil, W.; Weil, R.C.; Keawsompong, S.; Sriroth, K.; Seib, P.A.; Shi, Y.-C. Pyrodextrins from waxy and normal tapioca starches: Molecular structure and in vitro digestibility. Carbohydr. Polym. 2021, 252, 117140. [CrossRef]

36. Cao, Y.; Chen, X.; Sun, Y.; Shi, J.; Xu, X.; Shi, Y.-C. Hypoglycemic Effects of Pyrodextrins with Different Molecular Weights and Digestibilities in Mice with Diet Induced Obesity. J. Agric. Food Chem. 2018, 66, 2988-2995. [CrossRef]

37. Glaring, M.A.; Koch, C.B.; Blennow, A. Genotype-Specific Spatial Distribution of Starch Molecules in the Starch Granule: A Combined CLSM and SEM Approach. Biomacromolecules 2006, 7, 2310-2320. [CrossRef]

38. Svihus, B.; Uhlen, A.H.; Harstad, O.M. Effect of starch granule structure, associated components and processing on nutritive value of cereal starch: A review. Anim. Feed Sci. Technol. 2005, 122, 303-320. [CrossRef]

39. Lei, N.; Chai, S.; Xu, M.; Ji, J.; Mao, H.; Yan, S.; Gao, Y.; Li, H.; Wang, J.; Sun, B. Effect of dry heating treatment on multi-levels of structure and physicochemical properties of maize starch: A thermodynamic study. Int. J. Biol. Macromol. 2020, 147, 109-116. [CrossRef]

40. Singh, V.; Ali, S.Z.; Somashekar, R.; Mukherjee, P.S. Nature of crystallinity in native and acid modified starches. Int. J. Food Prop. 2006, 9, 845-854. [CrossRef]

41. Pozo, C.; Rodríguez-Llamazares, S.; Bouza, R.; Barral, L.; Castano, J.; Müller, N.; Restrepo, I. Study of the structural order of native starch granules using combined FTIR and XRD analysis. J. Polym. Res. 2018, 25, 266. [CrossRef] 
42. Rodriguez-Garcia, M.E.; Hernandez-Landaverde, M.A.; Delgado, J.M.; Ramirez-Gutierrez, C.F.; Ramirez-Cardona, M.; MillanMalo, B.M.; Londoño-Restrepo, S.M. Crystalline structures of the main components of starch. Curr. Opin. Food Sci. 2021, 37, 107-111. [CrossRef]

43. Wang, M.; Sun, M.; Zhang, Y.; Chen, Y.; Wu, Y.; Ouyang, J. Effect of microwave irradiation-retrogradation treatment on the digestive and physicochemical properties of starches with different crystallinity. Food Chem. 2019, 298, 125015. [CrossRef]

44. Remya, R.; Jyothia, A.N.; Sreekumar, J. Effect of chemical modification with citric acid on the physicochemical properties and resistant starch formation in different starches. Carbohydr. Polym. 2018, 202, 29-38. [CrossRef] [PubMed]

45. Martins, P.C.; Gutkokski, L.C.; Martin, V.G. Impact of acid hydrolysis and esterification process in rice and potato starch properties. Int. J. Biol. Macromol. 2018, 120, 959-965. [CrossRef]

46. Ba, K.; Blecker, C.; Danthine, S.; Tine, E.; Destain, J.; Thonart, P. Physicochemical characterization of dextrins prepared with amylases from sorghum malt. Starke 2013, 65, 962-968. [CrossRef]

47. Olvera-Hernández, V.; Ble-Castillo, J.-L.; Betancur-Ancona, D.; Acevedo-Fernández, J.-J.; Castellanos-Ruelas, A.; Chel-Guerrero, L. Effects of modified banana (Musa cavendish) starch on glycemic control and blood pressure in rats with high sucrose diet. Nutr. Hosp. 2018, 35, 588-595. [CrossRef]

48. Chen, P.; Liu, X.; Zhang, X.; Sangwan, P.; Yu, L. Phase transition of waxy and normal wheat starch granules during gelatinization. Int. J. Polym. Sci. 2015, 2015, 397128. [CrossRef]

49. Ubwa, S.T.; Abah, J.; Asemave, K.; Shambe, T. Studies on the gelatinization temperature of some cereal starches. Int. J. Chem. 2012, 4, 22-28. [CrossRef]

50. Hana, X.; Kangb, J.; Baib, Y.; Xueb, M.; Shib, Y. Structure of pyrodextrin in relation to its retrogradation properties. Food Chem. 2018, 242, 169-173. [CrossRef]

51. Nunes, F.M.; Lopes, E.S.; Moreira, A.S.P.; Simões, J.; Coimbra, M.A.; Domingues, R.M. Formation of type 4 resistant starch and maltodextrins from amylose and amylopectin upon dry heating: A model study. Carbohydr. Polym. 2016, 141, 253-262. [CrossRef] [PubMed]

52. Bai, Y.; Shi, Y.-C. Chemical structures in pyrodextrin determined by nuclear magnetic resonance spectroscopy. Carbohydr. Polym. 2016, 151, 426-433. [CrossRef] [PubMed]

53. Richter, M.; Augustat, S.; Schierbaum, F. Ausgewahlte Methoden der Stärkechemie; VEB Fachbuchverlag: Leipzig, Germany, 1968.

54. PN-A-A74701:1978, Hydrolizaty Skrobiowe (Krochmalowe)—Metody Badan. Available online: https://sklep.pkn.pl/pn-a-7470 1-1978p.html (accessed on 16 June 2021). (In Polish).

55. McCleary, B.V.; DeVries, J.W.; Rader, J.I.; Cohen, G.; Prosky, L.; Mugford, D.C.; Champ, M.; Okuma, K. Determination of Total Dietary Fiber (CODEX Definition) by Enzymatic-Gravimetric Method and Liquid Chromatography: Collaborative Study. J. AOAC Int. 2010, 93, 221-233. [CrossRef]

56. Hulleman, S.H.D.; Kalisvaart, M.G.; Janssen, F.H.P.; Feil, H.; Vliegenthart, J.F.G. Origins of B-type crystallinity in glycerolplasticised, compression-moulded potato starches. Carbohydr. Polym. 1999, 39, 351-360. [CrossRef]

57. Rosicka-Kaczmarek, J.; Tkaczyk, M.; Makowski, B.; Komisarczyk, A.; Nebesny, E. The influence of non-starch polysaccharide on thermodynamic properties of starches from facultative wheat varieties. Eur. Food Res. Technol. 2017, 243, 2243-2253. [CrossRef] 